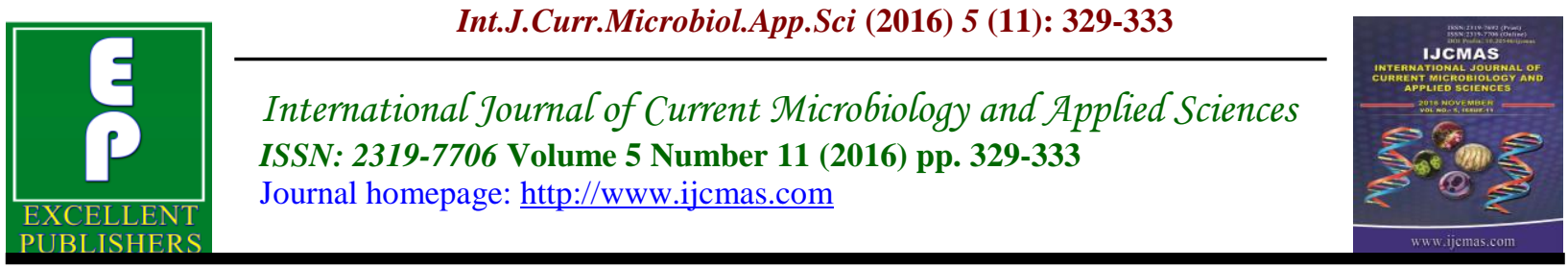

Original Research Article

http://dx.doi.org/10.20546/ijcmas.2016.511.036

\title{
A Retrospective Study on Seroprevalence of Hepatitis B Surface Antigen among Patients in a Tertiary Care Hospital, South India
}

\author{
T.V. Parimala* \\ Department of Microbiology, Shridevi Institute of Medical Sciences and Research Hospital, \\ NH4, Sira road, Tumkuru, India \\ *Corresponding author
}

\begin{tabular}{ll}
\hline & A B S T R A C T \\
\cline { 2 - 3 } Keyw ords & $\begin{array}{l}\text { Hepatitis B is a parentrally transmitted virus and is major public health problem } \\
\text { world wide. A diagnosis of HBV infection usually made by detection of Hepatitis } \\
\text { B Surface antigen (HBsAg) in the serum. This retrospective study was conducted } \\
\text { to determine the prevalence of Hepatitis B surface antigen among patients in a } \\
\text { Tertiary care hospital, Tumkuru, South India during a period from March 2015 - }\end{array}$ \\
$\begin{array}{l}\text { Hepatitis B, } \\
\text { HBsAg, }\end{array}$ & $\begin{array}{l}\text { February 2016.A4135 serum samples were screened for testing of HBsAg in the } \\
\text { serology section of Department of Microbiology during the study period. Samples }\end{array}$ \\
Immunisation. & $\begin{array}{l}\text { were tested for HBsAg by Rapid ICT using commercially available kits. } \\
\text { Seroprevalence of HBsAg was found to be 0.58\%.This study showed higher } \\
\text { prevalence in males (0.74\%) compared to females }(0.44 \%) . I t \text { was also observed } \\
\text { that prevalence is highest in (0.97\%) age group 41-50 years. In our study } \\
\text { prevalence was highest in the month of October and January (1\%).In compare to } \\
\text { other parts of India, the present study shows low prevalence of hepatitis B infection } \\
\text { in Tumkuru, Karnataka, South India. Immunisation with Hepatitis B vaccine helps } \\
\text { in reducing the hepatitis B infection. }\end{array}$ \\
\hline $\begin{array}{l}\text { Accepted: } \\
\text { 16 October 2016 } \\
\text { Available Online: } \\
\text { 10 November 2016 }\end{array}$
\end{tabular}

\section{Introduction}

Hepatitis B virus (HBV) causes a spectrum of disease from self limited hepatitis to acute fulminant \& chronic hepatitis which may result in sequele like liver cirrhosis \& hepatocellular carcinoma (Quadri et al., 2013). Hepatitis B virus infection (HBV) is a major health problem in many countries of the world especially those in Asia, the Middle East \& Africa (El Beltagy et al., 2008). About 2 billion people worldwide have been infected with the virus $\&$ about 350 million live with chronic infection (Huda et al., 2013). In the South
East region, the estimated burden of chronic HBV infection is 100 million. HBV is the second most common cause of acute viral hepatitis after HEV in India. Every year, one million Indians are at risk for HBV \& about one 100000 die from HBV infection (NCDC Newsletter, 2014).

Transmission of the virus occurs in community in 3 ways. First wave occurs during perinatal period when the virus is transmitted from infected mothers to infants during delivery and up to first year of life. 
Second wave of transmission occurs during childhood by horizontal spread through close contact with infected siblings father, relatives and friends. And the third wave of spread occurs during adult life through sexual contact, intravenous drug abuse, blood transfusion etc (Shrestha et al., 2012). Modes of transmission of HBV vary, since the virus is present in blood, saliva, semen, vaginal secretions, menstrual blood, \& in smaller quantities in perspiration, breast milk, tears and urine of the infected individuals (Onwuakor et al., 2014). Unscreened donate blood, unsafe therapeutic practices, including the use of inadequately sterilized needles and medical instruments, are the major routes of HBV transmission apart from sexual exposure in South East Asia regions (Negero et al., 2011).

Countries are classified on the basis of endemicity of Hepatitis B Virus (HBV) infection into high $(8 \%$ or more $)$, intermediate $(2-7 \%)$ or low $(<2 \%)$ incidence countries. The prevalence of chronic HBV infection in India ranges from $2-10 \%$ as shown by the different studies. India therefore comes under the intermediate and high endemicity category (Singh et al., 2009). The present study was undertaken to determine the prevalence of Hepatitis B surface antigen in a tertiary care hospital, Tumkur, Karnataka, South India and to compare the prevalence rates in different parts of the world.

\section{Materials and Methods}

This retrospective study was conducted at Department of Microbiology of Shridevi Institue of Medical Sciences and Research Hospital, Tumkuru, Karnataka, South India from March 2015 to February 2016. A $5 \mathrm{ml}$ of venous blood samples was collected by venepuncture from all patients who come with laboratory requisition for the testing of
HBsAg.Samples were allowed to clot at RT for about $30 \mathrm{~min}$ to $45 \mathrm{~min}$. Serum was separated by centrifugation at a speed of $3000 \mathrm{rpm}$ for 10 minutes All the serum samples were screened for HBsAg by Rapid Immunochromatic Technique (ICT using the commercially available kit (Diagnostic enterprises ) with reported sensitivity of $100 \%$ and specificity of $100 \%$.ICT is a rapid and sensitive method for the detection of HBsAg. All serum samples were tested as per the manufacturer's instructions.

Data were analysed with Microsoft excel.

\section{Results and Discussion}

A total of 4135 serum samples were received for detection of $\mathrm{HBsAg}$ during the period from March 2015 to Feb 2016. Of these, 24 serum samples reactive to $\mathrm{HBsAg}$ giving a seroprevalence rate of $0.58 \%$ in the study population (Table 1).

Regarding age, seroprevalence of $\mathrm{HBsAg}$ was highest $6(0.97 \%)$ in the age group 41 50 years, followed by $4(0.82 \%)$ in the age group of 51-60 years compared to younger age group 11-20 (0.26\%) (Table 2).

The prevalence of HBsAg $14(0.74 \%)$ in males and $10(0.44 \%)$ in females (Table 3$)$.

Prevalence was almost between $0.2-0.7 \%$ throughout the year but in the month of October and January the prevalence rate of HBsAg of $1 \%$ was observed (Table4).

Hepatitis B is a parenterally transmitted virus that has adapted for its existence to the basic human activities like close association, sex and child birth (Shrestha et al., 2012). Diagnosis of HBV infection is usually through serological and virological markers. Hepatitis B surface antigen (HBsAg) is the hallmark of HBV infection and is the first 
serological marker to appear in acute HBV infection, and persistence of $\mathrm{HBsAg}$ for more than six months suggests chronic HBV infection (Onwuakor et al., 2014).

Prevalence of Hepatitis B varies from country to country and depends upon a complex interplay of behavioral, environmental and host factors. In general, it is lowest in countries or area with high standards of living (eg: Australia, North America, North Europe) and highest in countries or areas were social economic level is lower (eg: China, South East Asia, South America).The reported prevalence of carrier in different population varies widely from $0.1 \%$ in the advanced countries to $20 \%$ in the developing nations. The carrier rate higher in the tropical than in the temperate regions (Behal et al., 2008).

In a retrospective study conducted between 2005 and 2006 in Korea, the prevalence rate was reported to be $12.7 \%$. In an 11 year surveillance study conducted in Pakistan, prevalence of $\mathrm{HBsAg}$ positivity was found to be $2.5 \%$ in 47043 patients, where as it was found to be $8.1 \%$ in2995 subjects from Dhaka, Bangladesh.

Prevalence of HBV was found to be $11.2 \%$ in Andean plateau region of Latin America, which is considered as low risk region (Turanoglu et al., 2013). In a study conducted in a hospital based population at Kathmandu Medical College Hospital, Nepal, the prevalence rate of viral Hepatitis B was found to be $2.5 \%$ (Sood et al., 2010). Prevalence of HBV was found to be $11.2 \%$ in Andean plateau region of Latin America, which is considered as low risk region (Turanoglu et al., 2013). In a study conducted in a hospital based population at Kathmandu Medical College Hospital, Nepal, the prevalence rate of viral Hepatitis B was found to be $2.5 \%$ (Sood et al., 2010).

Table.1 Prevalence of Hepatitis B surface Antigen (HBsAg) among Patients in a Tertiary Care Hospital

\begin{tabular}{|l|l|l|l|}
\hline Test & $\begin{array}{l}\text { Total No. of Samples } \\
\text { Received }\end{array}$ & $\begin{array}{l}\text { No. of HBsAg } \\
\text { Positive Samples }\end{array}$ & \% of Positive Samples \\
\hline HBsAg & 4135 & 24 & 0.58 \\
\hline
\end{tabular}

Table.2 Drug sensitivity profile of E.coli isolates against commonly used antibiotics Prevalence of Hepatitis B surface Antigen (HBsAg) in Different Age Group in a Tertiary Care Hospital

\begin{tabular}{|l|l|l|l|}
\hline $\begin{array}{l}\text { Age Group } \\
\text { (in Years) }\end{array}$ & $\begin{array}{l}\text { Total No. of Samples } \\
\text { Received }\end{array}$ & $\begin{array}{l}\text { No. of HBsAg } \\
\text { Positive Samples }\end{array}$ & \% of Positive Samples \\
\hline $1-10$ & 163 & 0 & 0 \\
\hline $11-20$ & 383 & 1 & 0.26 \\
\hline $21-30$ & 1243 & 5 & 0.40 \\
\hline $31-40$ & 704 & 4 & 0.56 \\
\hline $41-50$ & 616 & 6 & 0.97 \\
\hline $51-60$ & 486 & 4 & 0.82 \\
\hline$>60$ & 540 & 4 & 0.74 \\
\hline Total & 4135 & 24 & \\
\hline
\end{tabular}


Table.3 Prevalence of Hepatitis B Surface Antigen (HBsAg) in Relation to Gender of Patients in a Tertiary Care Hospital

\begin{tabular}{|l|l|l|l|}
\hline Gender & $\begin{array}{l}\text { Total No. of Samples } \\
\text { Received }\end{array}$ & $\begin{array}{l}\text { No. of HBsAg } \\
\text { Positive Samples }\end{array}$ & \% of Positive Samples \\
\hline Male & 1873 & 14 & 0.74 \\
\hline Female & 2262 & 10 & 0.44 \\
\hline Total & 4135 & 24 & \\
\hline
\end{tabular}

Table.4 Prevalence of Hepatitis B Surface Antigen (HBsAg) in Relation to Month wise Among Patients in a Tertiary Care Hospital

\begin{tabular}{|l|c|c|c|}
\hline Month & $\begin{array}{c}\text { Total No. of Samples } \\
\text { Received }\end{array}$ & $\begin{array}{c}\text { No. of HBsAg } \\
\text { Positive Samples }\end{array}$ & \% of Positive Samples \\
\hline March 2015 & 276 & 02 & 0.72 \\
\hline April 2015 & 359 & 01 & 0.27 \\
\hline May 2015 & 335 & 02 & 0.59 \\
\hline June 2015 & 377 & 02 & 0.53 \\
\hline July 2015 & 387 & 03 & 0.77 \\
\hline August 2015 & 383 & 00 & 0.00 \\
\hline September 2015 & 413 & 02 & 0.48 \\
\hline October 2015 & 369 & 04 & 1.08 \\
\hline November 2015 & 369 & 02 & 0.54 \\
\hline December 2015 & 259 & 02 & 0.77 \\
\hline January 2016 & 245 & 03 & 1.22 \\
\hline February 2016 & 363 & 01 & 0.27 \\
\hline Total & 4135 & 24 & \\
\hline
\end{tabular}

Present study revealed increasing trend of seroprevalence with advancing age. HBsAg positivity was significant in the age group 41-50 yrs and > 50 years compared to younger age group (<20yrs). The significant association of HBV markers with older ages could be due to the greater number of years of potential exposure, a lack of adult HB vaccination programs, and the lack of awareness of HBV infection in earlier decade (El Beltagy et al., 2008).

Many studies reported that seroprevalence of $\mathrm{HBV}$ infection higher in male patients than in females. In our study the seroprevalence of $\mathrm{HBV}$ infection was more in male patients $(0.7 \%)$ than in female patients $(0.4 \%)$. No plausible explanation has been given for the higher prevalence in male in the general population but probably females clear the HBV more efficiently as compared to males (Chakraborthy et al., 2014).

A study conducted by Qadiri et al., reported that higher prevalence in June-July (Qadri et al., 2013). Higher prevalence was observed in the month of October and January in the present study.

Still further studies are needed to evaluate prevalence of HBsAg in relation to different season.

According to the WHO classification, this part of Karnataka qualifies as a low 
prevalence area $(<2 \%)$ of hepatitis $\mathrm{B}$ infection. An ideal way to reduce the Hepatitis B infection is to implementation of immunization programs along with health education. This is not a community based study. Further, community based studies are required to better estimate the magnitude of hepatitis B infection

\section{References}

Behal, R., Jain, R., Behal, K.K., Bhagoliwal, A., Aggarwal, N., and Dhole, T.N. 2008. Seroprervelance and risk factors for hepatitis B virus among general population in Northern India. Arq. Gastroenterol., Vol.45 (2):Online.

Chakraborty, A., Pramanik, S.B., Roy, D.S., Sarkar, S., Sengupta, M., and Nandi, A. 2015. A Sentinel Surveillance Study on Prervelance of Hepatitis B infection in a Tertiary care Hospital in Eastern India. J. Dental and Med. Sci., Vol 14(2):7478.

El Beltagy, K.E., Al Balawi, I.A., Almuneef, M., and Memish, Z.A. 2008. Prervelance of hepatitis B virus markers among blood donors in a tertiary hospital in Tabuk, North Western Saudi Arabia. Int. J. Infect. Dis., 12: 495-499.

Huda, K.M., and Nasir, T.A. 2013. Trends in Prevalence of Hepatitis B (HBV) and Hepatitis $\mathrm{C}$ ( $\mathrm{HCV})$ virus infection among blood donors in Appolo Hospital, Dhaka, Bangladesh, 20072011. Pulse. Vol 6 (192):27-32. NCDC Newsletter, Vol 3 (1). 1-3.

Negero, A., Sisay, Z., and Medhin, G. 2011. Prevalence of Hepatitis B surface Antigen (HBsAg) among visitors of
Shashemene General Hospital voluntary counseling and testing centre. Bio med central Research Notes.4: 35.

Onwuakor, C.E., Eze, V.C., Nwankwo, L.U., and Iwu, J.O. 2014. Seroprervelance of Hepatitis B surface Antigen (HBsAg) amongst pregnant women attending Antenatal Clinic at the Federal Medical Centre Umuahia, Abia State, Nigeria. American J. Public Health Res., Vol 2(6): 255-259.

Quadri, S.A., Dadapeer, H.J., Arifulla, K.M., and Khan, N. 2013. Prevalence of Hepatitis B surface Antigen in hospital based population in Bijapur, Karnataka. Al Ameen J. Med. Sci., 6(2): 180-182.

Shrestha, S.M., and Shrestha, S. 2012. Chronic Hepatitis B in Nepal: An Asian Country with low prevalence of HBV infection. Tropical Gastro-enterol., Online.

Singh, K., Bhat, S., and Shastry, S. 2009. Trend in Seroprervelance of Hepatitis B virus among blood donors of coastal Karnataka, India. J. Infect. Dev. Ctries, Vol 3(5): 376-379.

Sood, S., and Malvankar, S. 2010. Seroprervelance of Hepatitis B surface antigen, antibodies to the Hepatitis C Virus, and Human immunodeficiency virus in a hospital based population in Jaipur, Rajasthan. Indian J. Community Med., Vol 35 (1): 165-169.

Turhanoglu, M., Onur, A., Bilman, F.B., Ayaydin, Z., and Aktar, G.S. 2013. Eight -year Seroprervelance of HBV, HCV and HIV in Diyarbakir Training and Research Hospital. Int. J. Med. Sci., 10(11): 1595-1601.

\section{How to cite this article:}

Parimala, T.V. 2016. A Retrospective Study on Seroprevalence of Hepatitis B Surface Antigen among Patients in a Tertiary Care Hospital, South India. Int.J.Curr.Microbiol.App.Sci. 5(11): 329-333. doi: http://dx.doi.org/10.20546/ijcmas.2016.511.036 